\title{
Macro- and Micronutrient Contents in Soils of a Chronosequence of Naturally Regenerated Birch Stands on Abandoned Agricultural Lands in Central Poland
}

\author{
Tomasz Gawęda $^{1, *}$, Stanisław Małek ${ }^{2}$ (D) Ewa Błońska ${ }^{2}$ (D) Andrzej M. Jagodziński ${ }^{3}$, Szymon Bijak ${ }^{4}(\mathbb{D})$ \\ and Michał Zasada ${ }^{4}$ (D) \\ 1 State Forests National Forest Holding, Bielsko Forest District, 43-382 Bielsko-Biała, Poland \\ 2 Department of Ecology and Silviculture, Faculty of Forestry, University of Agriculture in Kraków, \\ 31-425 Kraków, Poland; rlmalek@cyf-kr.edu.pl (S.M.); ewa.blonska@urk.edu.pl (E.B.) \\ 3 Institute of Dendrology, Polish Academy of Sciences, 62-035 Kórnik, Poland; amj@man.poznan.pl \\ 4 Institute of Forest Sciences, Warsaw University of Life Sciences-SGGW, 02-776 Warsaw, Poland; \\ szymon_bijak@sggw.edu.pl (S.B.); michal_zasada@sggw.edu.pl (M.Z.) \\ * Correspondence: tomasz.gaweda@katowice.lasy.gov.pl
}

check for updates

Citation: Gawęda, T.; Małek, S.; Błońska, E.; Jagodziński, A.M.; Bijak, S.; Zasada, M. Macro- and

Micronutrient Contents in Soils of a Chronosequence of Naturally Regenerated Birch Stands on Abandoned Agricultural Lands in Central Poland. Forests 2021, 12, 956. https: / / doi.org/10.3390/f12070956

Academic Editor: Timothy A. Martin

Received: 29 April 2021

Accepted: 15 July 2021

Published: 20 July 2021

Publisher's Note: MDPI stays neutral with regard to jurisdictional claims in published maps and institutional affiliations.

Copyright: (c) 2021 by the authors. Licensee MDPI, Basel, Switzerland. This article is an open access article distributed under the terms and conditions of the Creative Commons Attribution (CC BY) license (https:// creativecommons.org/licenses/by/ $4.0 /)$.

\begin{abstract}
Abandoned agricultural lands in Central and Northern Europe undergo a quite rapid secondary succession of woody species, especially silver birch (Betula pendula Roth.) as a pioneer tree species. Such a process is desirable both from natural and economic point of views, as afforestation involves a change to the entire ecosystem and, in particular, the transformation of anthropogenic habitats typical for agriculture into habitats similar to a natural forest. In the present study, we report the chemical properties of soils under birch stands that naturally regenerated on abandoned agricultural lands and answer the question of whether silver birch modifies the chemical properties of soils over a (relatively short-17 years) time and with depth in the soil profile. The research investigated the natural secondary succession of silver birch on 28 study plots established as a chronosequence in seven locations in Central Poland. The age of the stands ranged from 2 to 17 years. We analysed the contents of selected micro- and macroelements and heavy metals at three depths in the soil profile. The chemical properties of former agricultural soils covered with newly established silver birch stands, taking into account the depth in the soil profile, demonstrated tendencies to change over the time. In the first age class of birch stands, the stock of investigated nutrients in the soil was higher compared to the following age classes. Statistically significant differences were noted in the case of $\mathrm{Cu}$ and $\mathrm{Cr}$. Along with the age of birch stands (age class IV), there was a tendency for stock of the analysed nutrients to grow, which can be associated with an increase in aboveground biomass and root system development. The changes in the contents of the macro- and microelements, as well as heavy metals, were characterised by a gradual increase of the elements analysed in the upper layer of the soil that, in the years following the birch influence on the soil, starts having an effect on the deeper layers. In the case of $\mathrm{Cu}, \mathrm{Pb}, \mathrm{Cd}, \mathrm{Ni}$ and $\mathrm{Cr}$, there was a statistically significant change in the depth of the soil. Longer chronosequences should be observed to see a clear trajectory in soil chemistry changes with birch stand ages.
\end{abstract}

Keywords: natural regeneration; post-agricultural soils; afforestation; silver birch; soil properties; nutrients

\section{Introduction}

The afforestation of former agricultural land is a process that has received considerable socioeconomic attention in recent years [1-8]. Since the energy from renewable resources has been widely promoted, the production of large quantities of easily accessible and useable highly energetic biomass from trees has gained attention, leading to the publication of numerous research papers on the ecological processes for modelling such ecosystems (e.g., [9-20]). Many of the published papers also consider the environmental aspects, including carbon sequestration and allocation of elements (e.g., [21-26]). 
The process of afforestation of former agricultural areas is of concern not only in Poland but also in the Scandinavian and Baltic countries [21,27-29]. However, this phenomenon is limited to the planting and growing of trees on sites formerly used for agricultural purposes. Afforestation involves a change to the entire ecosystem and, in particular, the transformation of anthropogenic habitats typical for agriculture into habitats similar to a natural forest [4,29-31]. Such a transformation is only possible by the application of cover crop plantations, which are supposed to facilitate a smooth change between the two types of ecosystems. The most effective solution, from an ecological, as well as economical, point of view, is to support the naturally occurring processes of secondary succession [6,32,33]. In the Polish lowlands, as well as in other areas of eastern and northern parts of Europe, the predominant tree species that grows spontaneously on former agricultural lands is silver birch (Betula pendula Roth.) and, on the more humid habitats, downy birch (Betula pubescens Ehrh.) $[9,21,28,34-38]$. This is mainly because of their light, well-dispersed seeds, with frequent and abundant fruit-bearing abilities and the great elasticity of the habitat requirements of the species [37]. The birch, being an extremely light-demanding species, grows very rapidly and, thus, allows, even at an early age, to produce a considerable quantity of biomass for use by energy plants or by the paper industry $[10,37,39]$.

Several studies conducted in Europe have examined soil properties and their change in relation to secondary succession on former agricultural lands [40]. For example, Alriksson and Olsson [41] studied the effects of afforestation in different age classes (20, 40 and 55-57 years) of Norway spruce (Picea abies (L.) H. Karst.) on the soil properties and found that, in the litter layer, $\mathrm{pH}$ and $\mathrm{N}$, the $\mathrm{Ca}$ and $\mathrm{K}$ concentrations were significantly lower, whereas the C:N ratio was higher in the oldest stand in comparison with the younger ones. Wall and Hytönen [42] studied soil fertility changes under the influence of afforestation with Norway spruce in comparison with continuously forested sites. Studies in Norway spruce and oak stands established from 1969 to 1997 on former horticultural and agricultural soils in the vicinity of Copenhagen, Denmark were conducted by Ritter et al. [43]. Hagen-Thorn et al. [44] studied the influence of 30-40-year-old stands of common European tree species (Quercus robur L., Tilia cordata Mill., Fraxinus excelsior L., Betula pendula Roth., Fagus sylvatica L. and Picea abies (L.) H. Karst.) in former arable lands on the soil chemistry. They found that the soil characteristics differed significantly among species mainly in the upper soil layer $(0-10 \mathrm{~cm})$. The studies conducted by Podrázský at al. [45], as well as Kupka and Podrázský [46], concerned changes in the physical and chemical properties of soils under the influence of afforestation of former agricultural lands in the Czech Republic and showed that various tree species (i.e., Pinus sylvestris, Picea abies, Betula pendula and Pseudotsuga menziesii) influence upper soil horizons in diversified ways. Vesterdal et al. [47] found that the forest floor in a Norway spruce chronosequence sequestered $C$ at a significantly higher rate in comparison with oak stands. The carbon concentration in the upper $5 \mathrm{~cm}$ of the mineral soil increased significantly with the increasing stand age, whereas the C concentration tended to decrease with the soil depth. Smal and Olszewska [48] studied 14-17 and 32-36-year-old Scots pine stands growing on abandoned agricultural lands. The results showed lower $\mathrm{pH}$ in the A horizon of afforested soils in comparison with arable soils, and the greatest $\mathrm{pH}$ decrease was found in the $0-5-\mathrm{cm}$ soil layer. The soil organic carbon (SOC) content in the 0-5-cm layer was distinctly higher in the afforested soils than in arable soils and diminished with the soil depth. Soil depth influences the abundance, composition and functions of soil microbial communities [49]. The litter and greater root presence in surface horizons lead to changes of soil properties, especially the $\mathrm{pH}$, carbon content and biochemical activity [50].

Previous research has focused on the impact of a new generation of trees on acidification, as well as the quantity and quality of organic matter in soils of post-agricultural lands. There is no data, however, on the soil element changes over time, along with the development of silver birch stands in the first years of growth. Monitoring the amount of micro- and macroelements in soils is important for the nutrition of birch stands and the efficiency of nutrient cycles. So far, no detailed studies on the influence of naturally 
developed birch stands on soil properties in temperate climate have been conducted. Thus, the aim of our study was to determine the accumulation of the most important soil macroand micronutrients and heavy metals in a chronosequence of naturally developed birch stands growing on former agricultural lands. Micro- and macroelements are one of the factors conditioning plant growth. Micro- and macroelements are essential as catalysts for physiological processes such as the photosynthesis, respiration and formation of chlorophyll. For this study, we made the assumption that the effects of birch stands on soil properties change with the stand age. We suppose that, in soils of the oldest birch stands (IV age classes), the contents of micro- and macroelements increase as a result of higher plant biomass. We assume that the effects of the influence of birch stands can be visible not only in the surface soil horizon but, with the age of the stands, the influence can be visible in deeper soil horizons.

\section{Materials and Methods}

\subsection{Study Sites}

The materials for this study were collected at seven locations in Central Poland in pure silver birch stands naturally regenerated on post-agricultural lands (Table 1). The former farmland status (mostly cereal production) and the cessation of agricultural use were checked and confirmed by the owners and/or local administration. No silvicultural treatments or soil preparations were applied to any of these stands prior to our sampling (personal communications from forest authorities).

Table 1. Basic characteristics of the surveyed post-agricultural lands.

\begin{tabular}{|c|c|c|c|c|c|c|c|}
\hline \multicolumn{2}{|c|}{ Location } & \multirow{2}{*}{$\begin{array}{c}\begin{array}{c}\text { Age of Stands } \\
\text { (Years) }\end{array} \\
2-13\end{array}$} & \multirow{2}{*}{$\begin{array}{c}\text { Soil pH Range } \\
4.5-5.5\end{array}$} & \multirow{2}{*}{$\frac{\text { N/ha }}{12,500-1,555,556}$} & \multirow{2}{*}{$\begin{array}{c}\begin{array}{c}\mathbf{D}_{1.3} \\
(\mathbf{c m})\end{array} \\
0.20-5.32\end{array}$} & \multirow{2}{*}{$\begin{array}{c}\begin{array}{c}\mathbf{H} \\
(\mathbf{m})\end{array} \\
0.15-7.67\end{array}$} & \multirow{2}{*}{$\begin{array}{c}\begin{array}{c}\mathrm{V} \\
\left(\mathrm{m}^{3} / \mathrm{ha}\right)\end{array} \\
0.6068-145.1203\end{array}$} \\
\hline Dobieszyn 1 & $51^{\circ} 35^{\prime}$ N. $21^{\circ} 10^{\prime} \mathrm{E}$ & & & & & & \\
\hline Dobieszyn 2 & $51^{\circ} 33^{\prime}$ N. $21^{\circ} 09^{\prime} \mathrm{E}$ & 4-12 & $4.5-5.5$ & $3964-395,000$ & $0.36-7.47$ & $0.81-10.10$ & $1.5270-94.0797$ \\
\hline Siedlce & $52^{\circ} 03^{\prime}$ N. $21^{\circ} 56^{\prime} \mathrm{E}$ & $4-10$ & $<4.5$ & $2926-92,702$ & $0.56-6.43$ & $1.66-8.40$ & $6.9162-77.4781$ \\
\hline Kozienice & $51^{\circ} 24^{\prime}$ N. $21^{\circ} 26^{\prime} \mathrm{E}$ & $4-13$ & $4.5-5.5$ & $6293-81,624$ & $0.24-7.10$ & $1.24-10.50$ & $0.7856-149.1231$ \\
\hline Łochów 1 & $52^{\circ} 34^{\prime}$ N. $22^{\circ} 02^{\prime} \mathrm{E}$ & $4-16$ & $<4.5$ & $7632-46,585$ & $1.15-5.84$ & $2.07-10.44$ & 25.4733-119.6174 \\
\hline Łochów 2 & $52^{\circ} 34^{\prime}$ N. $22^{\circ} 01^{\prime} \mathrm{E}$ & $4-17$ & $<4.5$ & $3200-86,667$ & $0.98-7.99$ & $2.17-12.39$ & $33.1971-113.8394$ \\
\hline Kampinos & $52^{\circ} 21^{\prime}$ N. $20^{\circ} 43^{\prime} \mathrm{E}$ & $3-12$ & $4.5-5.5$ & 2987-198,095 & $0.22-8.35$ & $0.47-10.65$ & $0.6569-153.7627$ \\
\hline
\end{tabular}

$\mathrm{N} /$ ha-density, $\mathrm{D}_{1.3}$ - breast height diameter, $\mathrm{H}$-mean height and $\mathrm{V}$-growing stock.

All investigated sites are located in a transition zone from the maritime to the continental type within the temperate climate zone [51]. The annual average temperature ranges from $7.4^{\circ} \mathrm{C}$ (Siedlce) to $8.2^{\circ} \mathrm{C}$ (Kampinos). January is the coldest month, with the average temperature slightly below $-2{ }^{\circ} \mathrm{C}$ all over Central Poland. The highest temperature was recorded in July and ranges from $16^{\circ} \mathrm{C}$ at the southern sites (Dobieszyn and Kozienice) to $17.5^{\circ} \mathrm{C}$ at the northern ones (Kampinos). The investigated region has very low precipitation and suffers from occasional droughts. The average annual rainfall rarely exceeds $550-600 \mathrm{~mm}$. The field sites were located in an area dominated by Podzols, Luvisols and Cambisols [52]. Soils dominant in the study area were formed from similar geological substrates (glacial sand) and characterised by a similar texture (loamy sand) [53]. Depth of the former ploughing horizons was $30 \mathrm{~cm}$.

\subsection{Material Collection}

We chose 28 plots that constituted the chronosequence of silver birch stands consisting of four age classes: I $-2-4$ years (in total, 8 plots), II $-5-8$ years (6 plots), III $-9-12$ years ( 9 plots) and IV-13-17 years (5 plots).

At each plot, the soil samples were obtained with Kopecký cylinders [54] from three topsoil layers: $0-5-\mathrm{cm}, 5-15-\mathrm{cm}$ and $15-30-\mathrm{cm}$ depths. A composite soil sample from each horizon consisting of 3 subsamples from different points was collected. Collected samples were transported to the laboratory, where they were dried at $105^{\circ} \mathrm{C}$ and weighed. Particle density was determined by the pycnometric method and bulk density by the volume-weight method [55]. Concentrations of the following elements: $\mathrm{Na}, \mathrm{K}, \mathrm{Ca}, \mathrm{Mg}$, 
$\mathrm{Fe}, \mathrm{Mn}, \mathrm{Zn}, \mathrm{Cu}, \mathrm{Pb}, \mathrm{Cd}, \mathrm{Ni}$ and $\mathrm{Cr}$ were determined by the means of wet mineralisation in a $60 \%$ solution of $\mathrm{HClO}_{4}$ performed with an atomic absorption spectrometer (Varian AA-20-Varian Inc, Paolo Alto, CA, USA). Moreover, for each sample, weight by volume was determined at room temperature. The stock was calculated as the sum of mathematical products of the concentrations of the elements and the bulk density for the individual soil depths $(0-5 \mathrm{~cm}, 5-15 \mathrm{~cm}$ and $15-30 \mathrm{~cm})$ :

$$
\text { Stock of element }(\mathrm{kg} / \mathrm{ha})=\mathrm{C} \times \mathrm{BD} \times \mathrm{M} / 10
$$

where C—concentration of the micro- or macroelement $(\mathrm{mg} / \mathrm{kg}), \mathrm{BD}$-bulk density $\left(\mathrm{g} / \mathrm{cm}^{3}\right)$ and $\mathrm{M}-$ horizon depth $(\mathrm{cm})$.

The biomass $\left(\mathrm{kg} \cdot \mathrm{ha}^{-1}\right)$ of the aboveground and belowground parts of the stands in groups I-IV was determined. For this, 10 trees were randomly selected at each location and separated into trunk, branches, assimilation apparatus, bark and roots. All parts of the tree were weighed in the field using portable scales with an accuracy of $0.01 \mathrm{~g}$. Samples from each of the components were collected to determine the relationship between fresh and dry biomass. Briefly, the samples were oven-dried at $105^{\circ} \mathrm{C}$ and weighed. On the basis of appropriate fresh-to-dry mass ratios, we calculated the dry biomass of the components for each tree.

\subsection{Statistical Analyses}

Due to the mixed character of the data (quantitative and qualitative), we analysed the significance of the differences between the concentrations of individual elements among the age classes and depths in the soil profile with a generalised linear model (GLM). By analogy, the same method was used for an analysis of the contents of the investigated elements in the top 30-cm layer of soil, which was calculated based on the determined concentrations and weighed by volume. The obtained data did not show normality; the Shapiro-Wilk test was used to check the normal distribution. A Kruskal-Wallis test was used to assess significant differences between the mean values of the properties. A principal component analysis (PCA) was used to evaluate the relationships between the micro- and macroelements, age of stands and soil depth. The statistical package IBM SPSS Statistics version 22 [56] was used for the calculations. All analyses were performed at the $\alpha=0.05$ significance level.

\section{Results}

The studied stands differed in the aboveground and belowground biomass in different age classes (Figure 1). With age, we noted an increase in the aboveground and belowground biomass. In the case of the aboveground biomass, statistically significant differences in the biomass between the I and IV age classes were noted. Significant differences were also noted in the case of the root biomass (Figure 1). 

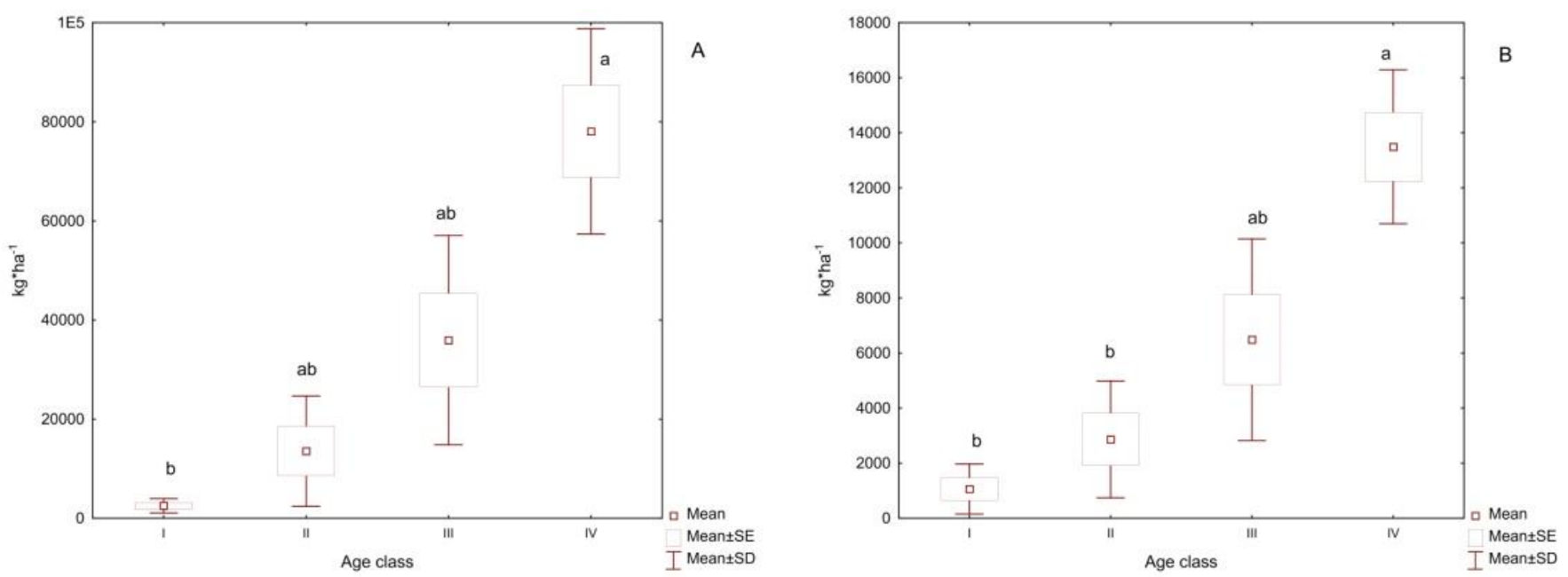

Figure 1. Average of aboveground (A) and belowground (B) biomass in the studied chronosequence (a,b mean significant differences of the soils properties between chronosequences).

For the $\mathrm{Na}, \mathrm{K}, \mathrm{Ca}$ and $\mathrm{Mg}$ contents, certain tendencies of change in the concentrations were observed, along with the age of the birch stands and depth of the profile (Table 2). In the $0-5-\mathrm{cm}$ layer, an increase was found in the concentrations of potassium and magnesium in relation to the age of the birch stand. The concentration of sodium fluctuated slightly; however, the calcium content in the soil had a considerable increase by age class IV after an initial drop in age classes I-III. However, these relationships were not statistically significant in any case.

Table 2. Mean (M) with standard error (SE) concentrations ( $\mathrm{mg} / \mathrm{kg}$ of the soil) of the macroelements in the three top layers of the soil $(0-5,5-15$ and $15-30 \mathrm{~cm})$ under silver birch regeneration by age class (I, II, III and IV-1-4, 5-8, 9-12 and 13-17 years, respectively).

\begin{tabular}{|c|c|c|c|c|c|c|c|c|}
\hline \multirow{2}{*}{ Age Class } & \multicolumn{2}{|c|}{$\mathrm{Na}$} & \multicolumn{2}{|c|}{$\mathbf{K}$} & \multicolumn{2}{|c|}{$\mathrm{Ca}$} & \multicolumn{2}{|c|}{$\mathrm{Mg}$} \\
\hline & $\mathbf{M}$ & SE & $\mathbf{M}$ & SE & $\mathbf{M}$ & SE & $\mathbf{M}$ & SE \\
\hline \multicolumn{9}{|c|}{$0-5 \mathrm{~cm}$} \\
\hline I & 39.93 & 4.40 & 428.50 & 101.77 & 438.75 & 58.87 & 277.50 & 47.51 \\
\hline II & 50.90 & 7.30 & 438.83 & 107.80 & 427.83 & 48.42 & 272.17 & 50.08 \\
\hline III & 49.98 & 6.80 & 478.33 & 108.92 & 382.78 & 50.73 & 299.22 & 53.61 \\
\hline IV & 42.56 & 8.05 & 531.60 & 92.49 & 462.40 & 111.36 & 380.20 & 76.77 \\
\hline \multicolumn{9}{|c|}{$5-15 \mathrm{~cm}$} \\
\hline I & 46.13 & 7.66 & 520.13 & 118.89 & 525.50 & 85.41 & 309.38 & 58.50 \\
\hline II & 50.77 & 7.41 & 431.83 & 124.94 & 389.00 & 53.01 & 275.50 & 53.16 \\
\hline III & 47.03 & 6.19 & 491.67 & 99.40 & 376.56 & 50.29 & 312.11 & 54.37 \\
\hline IV & 42.14 & 7.57 & 482.20 & 68.01 & 355.40 & 54.32 & 362.40 & 73.26 \\
\hline \multicolumn{9}{|c|}{$15-30 \mathrm{~cm}$} \\
\hline I & 52.16 & 9.70 & 569.13 & 106.46 & 477.13 & 55.63 & 392.63 & 67.82 \\
\hline II & 45.45 & 6.67 & 335.17 & 86.26 & 345.17 & 47.50 & 256.17 & 26.27 \\
\hline III & $\begin{array}{l}39.69 \\
39\end{array}$ & 4.34 & 431.22 & 90.11 & 355.56 & 55.70 & 322.67 & 62.46 \\
\hline IV & 44.20 & 7.30 & 476.60 & 36.03 & 354.60 & 28.35 & 423.80 & 98.11 \\
\hline $\mathrm{A}$ & \multicolumn{2}{|c|}{0.828} & \multicolumn{2}{|c|}{0.645} & \multicolumn{2}{|c|}{0.087} & \multicolumn{2}{|c|}{0.193} \\
\hline $\mathrm{D}$ & \multicolumn{2}{|c|}{0.975} & \multicolumn{2}{|c|}{0.931} & \multicolumn{2}{|c|}{0.597} & \multicolumn{2}{|c|}{0.607} \\
\hline $\mathrm{A} \times \mathrm{D}$ & \multicolumn{2}{|c|}{0.750} & \multicolumn{2}{|c|}{0.934} & \multicolumn{2}{|c|}{0.839} & \multicolumn{2}{|c|}{0.958} \\
\hline
\end{tabular}

A-test probability values ( $p$-value) for age effect, D—test probability values ( $p$-value) for depth effect and A $\times$ D-test probability values ( $p$-value) for a combined age $\times$ depth effect. A, D and A $\times$ D were determined using a general linear model.

A decrease in the concentration of calcium at a depth of $5-15 \mathrm{~cm}$ was also noticeable. In the deepest layer $(15-30 \mathrm{~cm})$, however, it remained at a constant level. Very little change in the concentration of sodium was noted. A decrease in the concentrations of potassium and magnesium occurred in the $15-30-\mathrm{cm}$ layer at the very beginning of the chronosequence, and then, at the end of the observed period, it clearly increased. 
Variability in the concentration of potassium was also observed, evidenced by high values of the standard error, nearing almost one-fourth of the average value. This value mainly decreased, along with age and depth.

Amongst the macroelements in the soils examined, potassium and calcium were characterised by the largest stocks to a 30-cm depth (Table 3). Stocks of sodium were the lowest, and, in consecutive years, decreased, although the differences were not substantial. Similar tendencies were observed for calcium content. The stocks of potassium and magnesium showed large variability without clear connections to the age of the newly established birch stands. After the initial decrease in their contents, an increase of these elements took place, whereas, in the last period, potassium remained approximately constant, while magnesium showed a further increase.

Table 3. Mean (M) with standard error (SE) stocks $(\mathrm{kg} / \mathrm{ha})$ of the macroelements in the top $(0-30 \mathrm{~cm})$ soil layer under silver birch regeneration by age class.

\begin{tabular}{ccccccccc}
\hline \multirow{2}{*}{ Age Class } & \multicolumn{2}{c}{ Na } & \multicolumn{2}{c}{ K } & \multicolumn{2}{c}{ Ca } & \multicolumn{2}{c}{ Mg } \\
\cline { 2 - 10 } & $\mathbf{M}$ & SE & M & SE & M & SE & M & SE \\
\hline I & 192.99 & 32.91 & 2090.7 & 403.4 & 1933.6 & 268.9 & 1373.9 & 226.9 \\
II & 186.65 & 23.41 & 1438.4 & 340.8 & 1447.7 & 165.8 & 1029.4 & 114.6 \\
III & 173.15 & 18.17 & 1805.1 & 342.7 & 1460.0 & 200.8 & 1251.3 & 211.8 \\
IV & 158.06 & 21.95 & 1792.3 & 177.7 & 1363.4 & 168.9 & 1467.7 & 319.3 \\
\hline A & \multicolumn{3}{c}{0.936} & \multicolumn{2}{c}{0.740} & \multicolumn{2}{c}{0.632} & 0.617 \\
\hline
\end{tabular}

Explanations the same as for Table 2.

For the microelements examined (Table 4), a distinct concentration increase with the age class of newly established birch stands was observed in the 0-5-cm layer for zinc and iron, and for iron, an increase was also observed in the 5-15-cm layer. These differences were statistically insignificant.

Table 4. Mean (M) with standard error (SE) concentrations ( $\mathrm{mg} / \mathrm{kg}$ of the soil) of the microelements in the three top layers $(0-5,5-15$ and $15-30 \mathrm{~cm})$ of the soil under silver birch regeneration by age class (I, II, III and IV-1-4, 5-8, 9-12 and 13-17 years, respectively).

\begin{tabular}{|c|c|c|c|c|c|c|c|c|}
\hline \multirow{2}{*}{ Age Class } & \multicolumn{2}{|c|}{$\mathrm{Cu}$} & \multicolumn{2}{|c|}{$\mathrm{Zn}$} & \multicolumn{2}{|c|}{ Mn } & \multicolumn{2}{|c|}{$\mathbf{F e}$} \\
\hline & $\mathbf{M}$ & SE & $\mathbf{M}$ & SE & $\mathbf{M}$ & SE & $\mathbf{M}$ & SE \\
\hline \multicolumn{9}{|c|}{$0-5 \mathrm{~cm}$} \\
\hline $\mathrm{I}$ & 2.28 & 0.33 & 11.19 & 0.86 & 41.29 & 15.01 & 2451.63 & 428.02 \\
\hline II & 1.88 & 0.24 & 12.22 & 2.09 & 68.43 & 24.04 & 2740.17 & 549.63 \\
\hline III & 2.03 & 0.35 & 12.52 & 1.83 & 74.24 & 21.98 & 2905.44 & 426.27 \\
\hline IV & 2.42 & 0.26 & 15.80 & 2.66 & 42.58 & 11.72 & 3158.80 & 714.36 \\
\hline \multicolumn{9}{|c|}{$5-15 \mathrm{~cm}$} \\
\hline I & 3.05 & 0.72 & 11.38 & 0.91 & 49.78 & 17.68 & 2746.63 & 514.31 \\
\hline II & 1.85 & 0.33 & 11.78 & 1.51 & 65.52 & 26.88 & 2824.50 & 548.99 \\
\hline III & 1.66 & 0.31 & 11.08 & 1.32 & 76.13 & 22.35 & 2954.89 & 399.07 \\
\hline IV & 2.14 & 0.07 & 13.29 & 2.85 & 83.86 & 37.24 & 3291.80 & 587.10 \\
\hline \multicolumn{9}{|c|}{$15-30 \mathrm{~cm}$} \\
\hline $\mathrm{I}$ & 1.54 & 0.38 & 10.71 & 1.26 & 62.30 & 21.58 & 3273.38 & 529.57 \\
\hline II & 1.08 & 0.29 & 8.07 & 0.60 & 49.02 & 12.14 & 2399.67 & 550.71 \\
\hline III & 1.17 & 0.28 & 9.20 & 0.95 & 46.00 & 10.64 & 2686.33 & 422.60 \\
\hline IV & 2.06 & 0.20 & 13.03 & 1.42 & 71.88 & 23.32 & 3191.00 & 444.20 \\
\hline A & \multicolumn{2}{|c|}{$0.034^{*}$} & \multicolumn{2}{|c|}{0.059} & \multicolumn{2}{|c|}{0.786} & \multicolumn{2}{|c|}{0.678} \\
\hline $\mathrm{D}$ & \multicolumn{2}{|c|}{0.013 * } & \multicolumn{2}{|c|}{0.051} & \multicolumn{2}{|c|}{0.665} & \multicolumn{2}{|c|}{0.928} \\
\hline$A \times D$ & \multicolumn{2}{|c|}{0.554} & \multicolumn{2}{|c|}{0.862} & \multicolumn{2}{|c|}{0.752} & \multicolumn{2}{|c|}{0.920} \\
\hline
\end{tabular}

Explanations the same as for Table 2. ${ }^{*}$ Indicates statistically significant differences at $\alpha=0.05$.

For copper, however, the influence of age of newly established birch stands, together with depth in the soil profile, were both statistically significant (Table 4). The pattern of copper concentration variance was found to be similar to that of zinc, with the values of the test probability close to the statistical significance. Significant variability in the manganese 
content was notable (the standard mean error in extreme cases was above one-third of its mean value).

In the microelement groups, an average stock reaching almost $12 \mathrm{t} / \mathrm{ha}$ was noted for iron (Table 5). These values changed slightly in time, and their differences were statistically insignificant. The manganese stock increased in time by over $42 \mathrm{~kg} / \mathrm{ha}$ in the course of the entire chronosequence. This $20 \%$ increase, however, was statistically insignificant. In the cases of zinc and copper, after a notable initial drop in their stocks from age class I to II of the newly established birch stands, the values increased in the subsequent years, but those differences were also statistically insignificant.

Table 5. Mean (M) with standard error (SE) stocks $(\mathrm{kg} / \mathrm{ha})$ of microelements in the top $(0-30 \mathrm{~cm})$ soil layer under silver birch regeneration by age class.

\begin{tabular}{ccccccccc}
\hline \multirow{2}{*}{ Age Class } & \multicolumn{2}{c}{$\mathbf{C u}$} & \multicolumn{2}{c}{ Zn } & \multicolumn{2}{c}{ Mn } & \multicolumn{2}{c}{ Fe } \\
\cline { 2 - 10 } & $\mathbf{M}$ & SE & M & SE & M & SE & M & SE \\
\hline I & 8.20 & 1.51 & 43.28 & 3.87 & 217.85 & 66.58 & 11,850 & 1952 \\
II & 5.73 & 1.08 & 39.51 & 3.71 & 221.86 & 63.04 & 10,208 & 2050 \\
III & 5.73 & 1.07 & 41.11 & 4.01 & 251.59 & 60.74 & 11,236 & 1511 \\
IV & 7.87 & 0.46 & 49.66 & 6.52 & 259.46 & 90.60 & 11,786 & 1852 \\
\hline A & \multicolumn{2}{c}{0.433} & \multicolumn{2}{c}{0.496} & \multicolumn{2}{c}{0.876} & 0.940 \\
\hline
\end{tabular}

Explanations the same as for Table 2.

Amongst the heavy metals analysed, only chromium did not demonstrate a statistically significant relationship between the concentration and soil depth (Table 6). The concentrations of lead and cadmium in the soil decreased with the depth, while that of nickel increased. The concentration of chromium revealed significant dependence on the age of the birch trees, showing a tendency to increase with the stand age. Similar trends were observed for nickel at all soil depths analysed and for lead in the 5-15-cm layer. These relationships, however, were not statistically significant. It was observed that the standard error (SE) regularly reached high values. It was rarely less than one-tenth of the average value, yet, for cadmium in the 15-30-cm layer, it was even higher than one-half. Lower standard error values were only noted for lead, but even in this case, the deviation from the average was close to one-third of its value.

Table 6. Mean (M) with standard error (SE) concentrations ( $\mathrm{mg} / \mathrm{kg}$ of the soil) of heavy metals in the three top layers $(0-5,5-15$ and $15-30 \mathrm{~cm})$ of the soil under silver birch regeneration by age class (I, II, III and IV-1-4, 5-8, 9-12 and 13-17 years, respectively).

\begin{tabular}{|c|c|c|c|c|c|c|c|c|}
\hline \multirow{2}{*}{ Age Class } & \multicolumn{2}{|c|}{$\mathrm{Pb}$} & \multicolumn{2}{|c|}{$\mathrm{Cd}$} & \multicolumn{2}{|c|}{$\mathrm{Ni}$} & \multicolumn{2}{|c|}{$\mathrm{Cr}$} \\
\hline & $\mathbf{M}$ & SE & $\mathbf{M}$ & SE & $\mathbf{M}$ & SE & $\mathbf{M}$ & SE \\
\hline \multicolumn{9}{|c|}{$0-5 \mathrm{~cm}$} \\
\hline $\mathrm{I}$ & 8.89 & 0.57 & 0.09 & 0.01 & 1.34 & 0.17 & 4.03 & 0.49 \\
\hline II & 8.16 & 0.67 & 0.08 & 0.01 & 1.42 & 0.19 & 4.00 & 0.58 \\
\hline III & 9.47 & 1.17 & 0.07 & 0.01 & 1.46 & 0.21 & 4.19 & 0.54 \\
\hline IV & 8.07 & 1.14 & 0.07 & 0.01 & 1.99 & 0.44 & 5.27 & 0.62 \\
\hline \multicolumn{9}{|c|}{$5-15 \mathrm{~cm}$} \\
\hline $\mathrm{I}$ & 8.55 & 0.33 & 0.08 & 0.02 & 1.49 & 0.20 & 4.47 & 0.47 \\
\hline II & 7.10 & 0.77 & 0.06 & 0.01 & 1.47 & 0.23 & 4.01 & 0.59 \\
\hline III & 9.49 & 1.11 & 0.06 & 0.01 & 1.53 & 0.21 & 4.39 & 0.51 \\
\hline IV & 9.24 & 0.59 & 0.07 & 0.01 & 2.11 & 0.52 & 5.27 & 0.67 \\
\hline \multicolumn{9}{|c|}{$15-30 \mathrm{~cm}$} \\
\hline $\mathrm{I}$ & 3.82 & 0.69 & 0.04 & 0.02 & 2.64 & 0.59 & 5.34 & 0.58 \\
\hline II & 2.34 & 0.23 & 0.03 & 0.01 & 1.96 & 0.30 & 3.52 & 0.63 \\
\hline III & 3.41 & 0.60 & 0.03 & 0.01 & 2.17 & 0.42 & 4.15 & 0.66 \\
\hline IV & 4.96 & 1.40 & 0.04 & 0.01 & 2.74 & 0.53 & 5.43 & 0.48 \\
\hline A & \multicolumn{2}{|c|}{0.102} & \multicolumn{2}{|c|}{0.492} & \multicolumn{2}{|c|}{0.185} & \multicolumn{2}{|c|}{0.036 * } \\
\hline $\mathrm{D}$ & \multicolumn{2}{|c|}{$<0.001^{*}$} & \multicolumn{2}{|c|}{$<0.001^{*}$} & \multicolumn{2}{|c|}{0.020 * } & \multicolumn{2}{|c|}{0.848} \\
\hline$A \times D$ & \multicolumn{2}{|c|}{0.695} & \multicolumn{2}{|c|}{0.993} & \multicolumn{2}{|c|}{0.949} & \multicolumn{2}{|c|}{0.798} \\
\hline
\end{tabular}

* Indicates statistically significant differences at $\alpha=0.05$. 
In the analysed soils, lead achieved the highest concentration among the investigated heavy metals (Table 7). The stock of chromium was a bit lower. In all cases, decreases were observed after the first period of birch growth, with increases in the subsequent age classes. The observed differences, however, had no statistical significance.

Table 7. Mean (M) with standard error (SE) stocks $(\mathrm{kg} / \mathrm{ha})$ of heavy metals in the top $(0-30 \mathrm{~cm})$ soil layer under silver birch regeneration by age class.

\begin{tabular}{|c|c|c|c|c|c|c|c|c|}
\hline \multirow{2}{*}{ Age Class } & \multicolumn{2}{|c|}{$\mathrm{Pb}$} & \multicolumn{2}{|c|}{$\mathrm{Cd}$} & \multicolumn{2}{|c|}{$\mathrm{Ni}$} & \multicolumn{2}{|c|}{$\mathrm{Cr}$} \\
\hline & $\mathbf{M}$ & SE & $\mathbf{M}$ & SE & $\mathbf{M}$ & SE & $\mathbf{M}$ & SE \\
\hline I & 23.71 & 1.46 & 0.23 & 0.05 & 8.26 & 1.53 & 19.15 & 1.71 \\
\hline II & 18.76 & 0.79 & 0.18 & 0.02 & 6.88 & 0.80 & 14.45 & 1.83 \\
\hline III & 24.91 & 2.05 & 0.19 & 0.04 & 7.34 & 1.17 & 16.65 & 1.94 \\
\hline IV & 24.55 & 2.66 & 0.20 & 0.04 & 8.96 & 1.87 & 19.70 & 1.88 \\
\hline $\mathrm{A}$ & \multicolumn{2}{|c|}{0.146} & \multicolumn{2}{|c|}{0.918} & \multicolumn{2}{|c|}{0.693} & \multicolumn{2}{|c|}{0.172} \\
\hline
\end{tabular}

Explanations the same as for Table 2.

The PCA analysis showed relationships between the micro- and macroelement contents, age class and soil depth (Figure 2). The two primary factors had a significant impact on the variances of the micro- and macroelement contents $(44.27 \%)$. The PCA analysis indicated relationships of the surface horizons of soil $(0-5$ and $5-15 \mathrm{~cm})$ with higher contents of $\mathrm{Cu}, \mathrm{Pb}$ and $\mathrm{Cd}$. The first and fourth age classes were characterised by higher contents of $\mathrm{Ca}, \mathrm{Na}, \mathrm{K}, \mathrm{Mg}, \mathrm{Fe}, \mathrm{Ni}, \mathrm{Mn}, \mathrm{Cr}$ and $\mathrm{Zn}$.

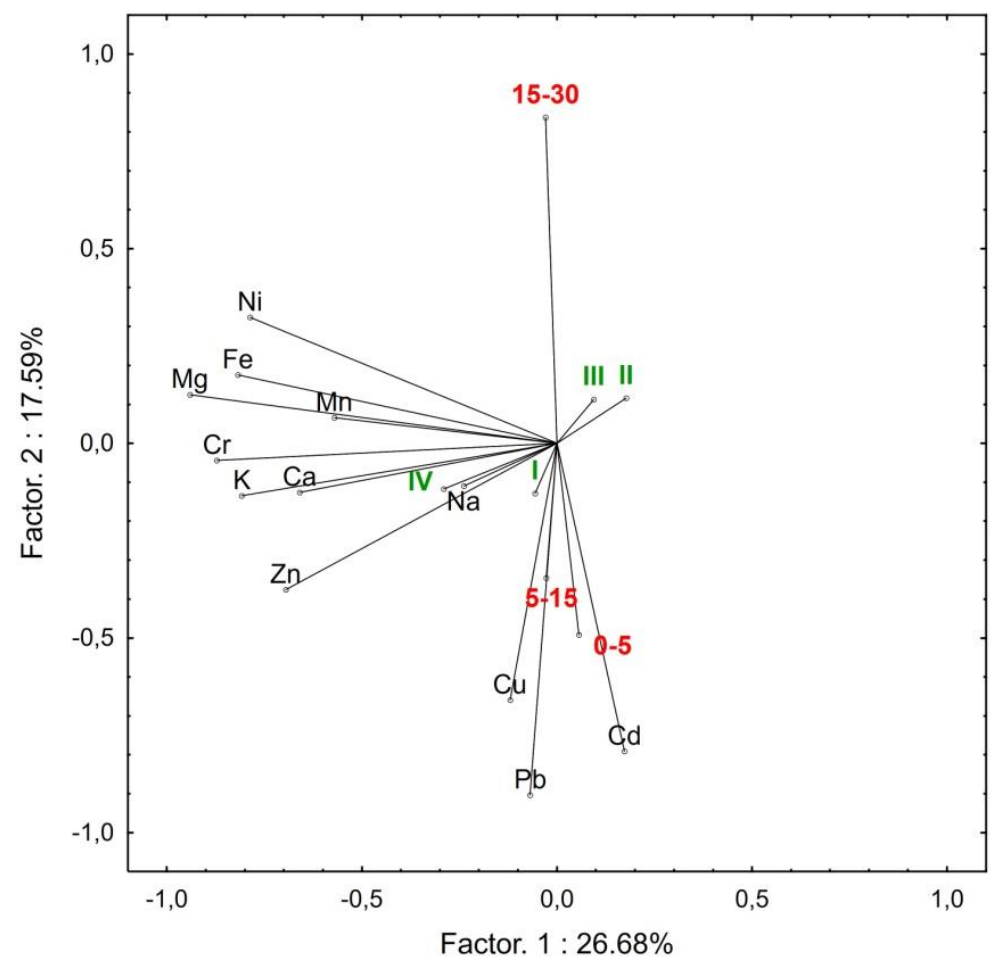

Figure 2. The projection of variables on a plane of the first and second PCA factors (I-IV-age class; 0-5, 5-15 and 15-30-soil depths).

\section{Discussion}

Our results did not fully confirm the expected assumptions. We noticed a tendency for changes in the contents of macro- and micronutrients in soils, along with the age of birch stands. In the first age class of birch stands, the stocks of $\mathrm{Na}, \mathrm{K}, \mathrm{Ca}$ and $\mathrm{Mg}$ in soils were higher compared to the following age classes (especially age classes II and III). This may 
be the result of past agricultural use. Arable soils are relatively rich in nitrogen and other macro- and micronutrients, especially if they were regularly fertilised. Post-agricultural soils show lower acidity and higher contents of nutrients as a residue after systematic fertilisation [57]. Along with the age of birch stands, there is a tendency of growing contents of $\mathrm{Cu}, \mathrm{Zn}, \mathrm{Fe}, \mathrm{PB}, \mathrm{Ni}$ and $\mathrm{Cr}$, which can be associated with an increase in aboveground biomass and root systems. Our research confirmed a statistically significant increase in aboveground and underground biomass in subsequent age classes. Litter addition, decomposition, release and return of nutrients to the soil system makes for very closed nutrient cycling in the forestry system. The biological atmospheric nitrogen fixation and carbon sequestration (soil) helps to improve the soil nutrient status. A common direction of changes in the concentrations and contents for macro- and microelements, as well as heavy metals, was observed for investigated soils on former agricultural lands now covered with newly established birch stands. These changes were characterised by a gradual increase of analysed elements in the upper layer of the soil that, in the years following the birch influence on the soil, has started to have an effect on the deeper layers. We found statistically significant correlations between the concentration and depth at which the soil samples were collected, as well as the age class of birch trees, for only a few of the elements examined. Changes in land cover (deforestation/afforestation) are directly responsible for the physiochemical properties of the soil [58-65]. Results of a clay soil analysis in the Sudeten Mountains (Southwestern Poland) conducted by Łętowska and Strączyńska [66] clearly showed that permanent fallowing of agricultural soil caused a substantial reduction of the potassium content but simultaneously led to an increase in the magnesium content. Similar conclusions come from the studies conducted by Straczyńska and Zawieja [67]. The concentration of Na did not change with the duration of fallowing, which confirms the observations presented in our study. Similar to the studies presented here, Smal et al. [68,69] noted a distinct drop in the contents of $\mathrm{Ca}, \mathrm{Mg}$ and $\mathrm{K}$ very soon after afforestation of the area. During further growth of the forest stands, however, increases of those elements always achieved levels similar to the original ones. Only the Na concentration remained unchanged. Brożek and Zwydak [70] obtained results very similar to those presented in this study, as far as concentrations of $\mathrm{Mg}, \mathrm{Na}, \mathrm{Cu}, \mathrm{Zn}, \mathrm{Mn}$ and all heavy metals in the Haplic Luvisol soil covered with aspen-birch forest stands are concerned. The cited authors also noted a substantially lower, in comparison to this study, concentration of $\mathrm{K}$ and higher concentrations of $\mathrm{Ca}$ and Fe. Such a pattern may be possible due to much more advanced processes of minerals flushing deeper into the soil profile in the case of forest soil. Our research covered sandy soils, which are characterised by a low sorption capacity and, at the same time, are susceptible to large losses of components as a result of leaching. Low concentration of $\mathrm{K}$ in the soil of former agricultural land is most probably caused by fallowing of the land and the fast passage of this element deeper into the profile, which was confirmed by the results of Łętowska and Strączyńska [66], as well as Strączyńska and Zawieja [67]. The soils included in our study were characterised by a sandy texture, and as a result, some of the components easily penetrated to deeper horizons. Soils dominated by the sand fraction have a low sorption capacity that can be improved by increasing the soil organic matter stock.

Tullus et al. [29] compared 14-20-year-old planted silver birch plantations and naturally regenerated birch stands, both growing on former agricultural lands. Podrázský and Ulbrichová [71] pointed out the highly ameliorative effect of 28-37-year-old birch stands on permanently fallowed agricultural soils. The contents of $\mathrm{P}, \mathrm{K}, \mathrm{Ca}$ and $\mathrm{Mg}$ in the upper soil layers under this pioneer species were the highest amongst the species studied ( $B$. pendula, Quercus rubra, Larix decidua and Picea abies), resulting in the best revitalisation effect on the soil. Podrázský and Ulbrichová [71] studied a much wider range of the profile but at an equal age, which went further than our experience. It is possible, however, to assume that their results can also depict the direction of further changes in the soil profile expected for the sample plots described in this study. In our study, we performed analyses for relatively young stands, up to 17 years old. The results obtained by us supplemented 
the missing information on the amount of micro- and macroelements in soils on abandoned agricultural lands in the first period of stand growth. The results provided the basis for the further monitoring of changes. The other studies described in the literature dealt with older stands or covered much longer timespans. Alriksson and Olsson [41] analysed a chronosequence starting from the age of 20 years. Uri et al. [72] investigated birches aged 20-78, while Varik et al. [73] studied birches over an age span of 6-60. In many studies [42,43,48], chronosequences finish at ages 30-40 years. Vesterdal et al. [42] studied oak and spruce stands and emphasised that the forest floor began to accumulate $\mathrm{C}$ only in tree stands older than 8 years. Additionally, the study of Ritter et al. [43] showed that the first significant differences (in that case, in $\mathrm{pH}$ ) appeared in tree stands at the age of 30. Summing up, our research supplements the missing information on the contents of microand macroelements in soils of post-agricultural lands. It is justified to continue research on plots with birch trees, especially in times of changing climatic conditions.

\section{Conclusions}

Micro- and macroelement contents of former agricultural soils covered with newly established silver birch stands, taking into account the depth in the soil profile, demonstrated tendencies for changes over time. We noticed a tendency for changes in the contents of $\mathrm{Cr}$ and $\mathrm{Cu}$ in soils with the age of birch stands. In the first age class of birch stands, the stock in the soil of the nutrients $(\mathrm{Cu})$ was higher compared to the following age classes. This may be the result of past agricultural use. Along with the age of birch stands (age class IV), there was a tendency for the selected nutrient contents to grow, which can be associated with an increase in aboveground biomass and root systems. Our research confirmed a statistically significant increase in aboveground and underground biomass in the subsequent age classes. The changes in the contents for the macro- and microelements, as well as heavy metals, were characterised by gradual increases of the elements analysed in the upper layer of the soil that, in the years following the birch influence on the soil, has started to have an effect on the deeper layers. The conducted research confirms that the afforestation of former agricultural lands leads to changes in the soil properties but very slowly. In the future, research should be continued, taking into account the quantity and quality of soil organic matter.

Author Contributions: Conceptualisation, T.G.; methodology, T.G., S.M. and S.B.; software, S.B. and E.B.; validation, S.M., M.Z. and A.M.J.; formal analysis, T.G., E.B. and S.B.; investigation, T.G.; resources, M.Z., S.B. and S.M.; data curation, T.G. and S.B.; writing-original draft preparation, T.G.; writing-review and editing, A.M.J., M.Z., S.B., S.M. and E.B.; visualisation, T.G.; supervision, S.M. and M.Z.; project administration, T.G. and funding acquisition, M.Z. and S.M. All authors have read and agreed to the published version of the manuscript.

Funding: This research was supported by the Polish National Science Centre within grant no. N305 400238, entitled "Ecological consequences of the silver birch (Betula pendula Roth.) secondary succession on abandoned farmlands in central Poland".

Institutional Review Board Statement: Not applicable.

Informed Consent Statement: Not applicable.

Data Availability Statement: Data is contained within the article.

Acknowledgments: We kindly thank Lee E. Frelich (The University of Minnesota Centre for Forest Ecology, USA) for the valuable comments and linguistic revision of the manuscript.

Conflicts of Interest: The authors declare no conflict of interest. The funders had no role in the design of the study; in the collection, analyses or interpretation of the data; in the writing of the manuscript or in the decision to publish the results. 


\section{References}

1. Bürgi, M.; Hersperger, A.M.; Schneeberger, N. Driving forces of landscape change-Current and new directions. Landsc. Ecol. 2004, 19, 857-868. [CrossRef]

2. Hietel, E.; Waldhardt, R.; Otte, A. Analysing land-cover changes in relation to environmental variables in Hesse, Germany. Landsc. Ecol. 2004, 19, 473-489. [CrossRef]

3. Behan, J.; McQuinn, K.; Roche, M.J. Rural land use: Traditional agriculture or forestry. Land Econ. 2006, 82, 112-123. [CrossRef]

4. Rey Benayas, J.M.; Martins, A.; Nicolau, J.M.; Schulz, J.J. Abandonment of agricultural land: An overview of drivers and consequences. CAB Rev. Perspect. Agric. Vet. Sci. Nutr. Nat. Resour. 2007, 2, 1-14. [CrossRef]

5. Łowicki, D. Land use changes in Poland during transformation: Case study of Wielkopolska region. Landsc. Urban Plan. 2008, 87, 279-288. [CrossRef]

6. Ruskule, A.; Nikodemus, O.; Kasparinska, Z.; Kasparinskis, R.; Brūmelis, G. Patterns of afforestation on abandoned agriculture land in Latvia. Agrofor. Syst. 2012, 85, 215-231. [CrossRef]

7. Lutter, R.; Tullus, A.; Kanal, A.; Tullus, T.; Vares, A.; Tullus, H. Growth development and plant-soil relations in midterm silver birch (Betula pendula Roth) plantations on previous agricultural lands in hemiboreal Estonia. Eur. J. For. Res. 2015, 134. [CrossRef]

8. Deptuła, M.; Nienartowicz, A.; Iwicka, M.; Filbrandt-Czaja, A. Biomass of Scots pine-silver birch tree stand 25 years after afforestation of former agricultural land. Ecol. Quest. 2017, 25, 51-66. [CrossRef]

9. Johansson, T. Biomass equations for determining functions of pendula and pubescent birches growing on abandoned farmland and some practical implications. Biomass Bioenergy 1999, 16, 223-238. [CrossRef]

10. Johansson, T. Biomass production and allometric above- and below-ground relations for young birch stands planted at four spacings on abandoned farmland. Forestry 2007, 80, 41-52. [CrossRef]

11. Varik, M.; Aosaar, J.; Uri, V. Biomass production in silver birch stands in Oxalis site type. For. Stud. 2009, 51, 5-16. [CrossRef]

12. Uri, V.; Varik, M.; Aosaar, J.; Kanal, A.; Kukumägi, M.; Lõhmus, K. Biomass production and carbon sequestration in a fertile silver birch (Betula pendula Roth) forest chronosequence. For. Ecol. Manag. 2012, 267, 117-126. [CrossRef]

13. Bijak, S.; Zasada, M.; Bronisz, A.; Bronisz, K.; Czajkowski, M.; Ludwisiak, Ł.; Tomusiak, R.; Wojtan, R. Estimating coarse roots biomass in young silver birch (Betula pendula) stands on post-agricultural lands in central Poland. Silva Fenn. 2013, 47, 1-14. [CrossRef]

14. Zasada, M. Modelowanie rozkładów pierśnic młodocianych drzewostanów brzozy brodawkowatej na gruntach porolnych za pomoca dwuparametrowego rozkładu Weibulla (Modeling dbh distribution of young silver birch stands on former agricultural lands with the 2-parameter Weibull distribution). Sylwan 2013, 157, 268-277. (In Polish)

15. Bijak, S.; Bronisz, K.; Szydłowska, P.; Wojtan, R. Wpływ jakości siedliska na dynamikę wydzielania brzozy na gruntach porolnych. Sylwan 2014, 158, 423-430. (In Polish)

16. Socha, J.; Zasada, M. Zagęszczenie i tempo naturalnego wydzielania w młodocianych drzewostanach brzozowych na gruntach porolnych. Sylwan 2014, 158, 340-351. (In Polish)

17. Zasada, M.; Bijak, S.; Bronisz, K.; Bronisz, A.; Gawęda, T. Biomass dynamics in young silver birch stands on post-agricultural lands in central Poland. Drewno 2014, 57, 29-39.

18. Repola, J. Biomass equations for birch in Finland. Silva Fenn. 2008, 42, 605-624. [CrossRef]

19. Akhtari, S.; Sowlati, T.; Day, K. Economic feasibility of utilizing forest biomass in district energy systems-A review. Renew. Sustain. Energy Rev. 2014, 33, 117-127. [CrossRef]

20. Lauri, P.; Havlík, P.; Kindermann, G.; Forsell, N.; Böttcher, H.; Obersteiner, M. Woody biomass energy potential in 2050. Energy Policy 2014, 66, 19-31. [CrossRef]

21. Uri, V.; Vares, A.; Tullus, H.; Kanal, A. Above-ground biomass production and nutrient accumulation in young stands of silver birch on abandoned agricultural land. Biomass Bioenergy 2007, 31, 195-204. [CrossRef]

22. Uri, V.; Lõhmus, K.; Ostonen, I.; Tullus, H.; Lastik, R.; Vildo, M. Biomass production, foliar and root characteristics and nutrient accumulation in young silver birch (Betula pendula Roth.) stand growing on abandoned agricultural land. Eur. J. For. Res. 2007, 126, 495-506. [CrossRef]

23. Gawęda, T.; Małek, S.; Zasada, M.; Jagodziński, A.M. Allocation of elements in a chronosequence of silver birch afforested on former agricultural lands. Drewno 2014, 57, 107-118.

24. Piché, N.; Kelting, D.L. Recovery of soil productivity with forest succession on abandoned agricultural land. Restor. Ecol. 2015, 23, 645-654. [CrossRef]

25. Aosaar, J.; Mander, Ü.; Varik, M.; Becker, H.; Morozov, G.; Maddison, M.; Uri, V. Biomass production and nitrogen balance of naturally afforested silver birch (Betula pendula Roth.) stand in Estonia. Silva Fenn. 2016, 50, 1-19. [CrossRef]

26. Gawęda, T.; Błońska, E.; Małek, S.; Bijak, S.; Zasada, M. Zastosowanie ITGL w ocenie gleb porolnych z naturalnym odnowieniem brzozy. Sylwan 2018, 162, 396-402. (In Polish)

27. Karlsson, A.; Albrektson, A.; Forsgren, A.; Svensson, L. An analysis of successful natural regeneration of downy and silver birch on abandoned farmland in Sweden. Silva Fenn. 1998, 32, 229-240. [CrossRef]

28. Liepins, K. First-year height growth of silver birch in farmland depending on container stock morphological traits. Balt. For. 2007, $13,54-60$.

29. Tullus, T.; Tullus, A.; Roosaluste, E.; Kaasik, A.; Lutter, R.; Tullus, H. Understorey vegetation in young naturally regenerated and planted birch (Betula spp.) stands on abandoned agricultural land. New For. 2013, 44, 591-611. [CrossRef] 
30. Flinn, K.M.; Vellend, M. Recovery of forest plant communities in post-agricultural landscapes. Front. Ecol. Environ. 2005, 3, 243-250. [CrossRef]

31. Rūsina, S.; Bambe, B.; Daugaviete, M. Changes in ground vegetation of arable lands under afforestation in Latvia. Balt. For. 2011, $17,243-255$.

32. Jõgiste, K.; Vares, A.; Sendrós, M. Restoration of former agricultural fields in Estonia: Comparative growth of planted and naturally regenerated birch. Forestry 2003, 76, 209-219. [CrossRef]

33. Prach, K.; Pyšek, P. Using spontaneous succession for restoration of human-disturbed habitats: Experience from Central Europe. Ecol. Eng. 2001, 17, 55-62. [CrossRef]

34. Bernadzki, E. Koncepcje hodowli lasu na gruntach porolnych. Sylwan 1990, 134, 51-59. (In Polish)

35. Jakubowski, G.; Sobczak, R. Możliwości intensywnej uprawy sosny i brzozy na gruntach porolnych. Pr. Inst. Badaw. Leśnictwa 1999, 878, 61-93. (In Polish)

36. Hynynen, J.; Niemistö, P.; Viherä-Aarnio, A.; Brunner, A.; Hein, S.; Velling, P. Silviculture of birch (Betula pendula Roth. and Betula pubescens Ehrh.) in northern Europe. Forestry 2010, 83, 103-119. [CrossRef]

37. Cameron, A.D. Managing birch woodlands for the production of quality timber. Forestry 1996, 69, 357-371. [CrossRef]

38. Bernadzki, E.; Kowalski, M. Brzoza na gruntach porolnych. Sylwan 1983, 127, 33-42. (In Polish)

39. Kund, M.; Vares, A.; Sims, A.; Tullus, H.; Uri, V. Early growth and development of silver birch (Betula pendula Roth.) plantations on abandoned agricultural land. Eur. J. For. Res. 2010, 129, 679-688. [CrossRef]

40. Piasta, A.; Skorupski, M.; Pastwik, E.; Zasada, M. Change of Mesostigmata mite fauna caused by silver birch (Betula pendula Roth.) secondary natural succession on agricultural fields. In Science for Sustainability, Proceedings of the International Scientific Conference for PhD Students, Győr, Hungary, 19-20 March 2013; Neményi, M., Varga, L., Facskó, F., Lőrincz, I., Eds.; University of West Hungary Press: Sopron, Hungary, 2013; pp. 160-166.

41. Alriksson, A.; Olsson, M.T. Soil changes in different age classes of Norway spruce (Picea abies (L.) Karst.) on afforested farmland. Plant Soil 1995, 168-169, 103-110. [CrossRef]

42. Vesterdal, L.; Ritter, E.; Gundersen, P. Change in soil organic carbon following afforestation of former arable land. For. Ecol. Manag. 2002, 169, 137-147. [CrossRef]

43. Ritter, E.; Vesterdal, L.; Gundersen, P. Changes in soil properties after afforestation of former intensively managed soils with oak and Norway spruce. Plant Soil 2003, 249, 319-330. [CrossRef]

44. Hagen-Thorn, A.; Callesen, I.; Armolaitis, K.; Nihlgård, B. The impact of six European tree species on the chemistry of mineral topsoil in forest plantations on former agricultural land. For. Ecol. Manag. 2004, 195, 373-384. [CrossRef]

45. Podrázský, V.; Remeš1, J.; Hart, V.; Keith Moser, W. Production and humus form development in forest stands established on agricultural lands-Kostelec nad Černými lesy region. J. For. Sci. 2009, 55, 299-305. [CrossRef]

46. Kupka, I.; Podrázský, V. Species composition effects of forest stands on afforested agricultural land on the soil properties. Sci. Agric. Bohem. 2011, 42, 19-23.

47. Wall, A.; Hytönen, J. Soil fertility of afforested arable land compared to continuously. Plant Soil 2005, 275, 247-260. [CrossRef]

48. Smal, H.; Olszewska, M. The effect of afforestation with Scots pine (Pinus sylvestris L.) of sandy post-arable soils on their selected properties. II. Reaction, carbon, nitrogen and phosphorus. Plant Soil 2008, 305, 171-187. [CrossRef]

49. Stone, M.M.; DeForest, J.L.; Plante, A.F. Changes in extracellular enzyme activity and microbial community structure with soil depth at the Luguillo Critical Zone Observatory. Soil Biol. Biochem. 2014, 75, 237-247. [CrossRef]

50. Błońska, E.; Lasota, J.; Rocha Vasconcelos da Silva, G.; Vanguelova, E.; Ashwood, F.; Tibbett, M.; Watts, K.; Lukac, M. Soil organic matter stabilization and carbon-cycling enzyme activity are affected by land management. Ann. For. Res. 2020, 63, 71-86.

51. Martyn, D. Klimaty Kuli Ziemskiej (Climates of the Earth); PWN: Warszawa, Poland, 2000.

52. IUSS Working Group WRB. World reference base for soil resources 2014, update 2015: International soil classification system for naming soils and creating legends for soil maps. World Soil Resour. Rep. 2015, 106, 192.

53. Gawęda, T.; Błońska, E.; Małek, S. Soil organic carbon accumulation in post-agricultural soils under the influence birch stands. Sustainability 2019, 11, 4300. [CrossRef]

54. Šarapatka, B. The Contribution of Czech Soil Science at the Turn of the 19th and 20th Centuries to Knowledge of Soils: In Memory of Professor Josef Kopecký. Soil Water Res. 2015, 10, 207-209. [CrossRef]

55. Ostrowska, A.; Gawliński, S.; Szczubiałka, Z. Metody Analizy I Oceny Właściwości Gleb I Roślin; Instytut Ochrony Środowiska: Warszawa, Poland, 1991; ISBN 83-85805-69-9.

56. IBM Corp. IBM SPSS Statistics for Windows; Version 22.0; IBM Corp.: Armonk, NY, USA, 2013.

57. Tuszyński, M. Properties of post-agricultural soils and forest economy. Sylwan 1990, 134, 41-49.

58. Reynolds, B.; Neal, C.; Hornung, M.; Hughes, S.; Stevens, P.A. Impact of afforestation on the soil solution chemistry of stagnopodzols in mid-Wales. Water Air Soil Pollut. 1988, 38, 55-70.

59. Strobel, B.W.; Hansen, H.C.B.; Borggaard, O.K.; Andersen, M.K.; Raulund-Rasmussen, K. Composition and reactivity of DOC in forest floor soil solutions in relation to tree species and soil type. Biogeochemistry 2001, 56, 1-26. [CrossRef]

60. Hooker, T.D.; Compton, J.E. Forest ecosystem carbon and nitrogen accumulation during the first century after agricultural abandonment. Ecol. Appl. 2003, 13, 299-313. [CrossRef]

61. Olszewska, M.; Smal, H. The effect of afforestation with Scots pine (Pinus sylvestris L.) of sandy post-arable soils on their selected properties. I. Physical and sorptive properties. Plant Soil 2008, 305, 157-169. [CrossRef] 
62. Berthrong, S.T.; Jobbágy, E.G.; Jackson, R.B. A global meta-analysis of soil exchangeable cations, pH, carbon, and nitrogen with afforestation. Ecol. Appl. 2009, 19, 2228-2241. [CrossRef]

63. Macdonald, C.A.; Thomas, N.; Robinson, L.; Tate, K.R.; Ross, D.J.; Dando, J.; Singh, B.K. Physiological, biochemical and molecular responses of the soil microbial community after afforestation of pastures with Pinus radiata. Soil Biol. Biochem. 2009, 41, $1642-1651$. [CrossRef]

64. Zhang, K.; Dang, H.; Tan, S.; Wang, Z.; Zhang, Q. Vegetation community and soil characteristics of abandoned agricultural land and pine plantation in the Qinling Mountains, China. For. Ecol. Manag. 2010, 259, 2036-2047. [CrossRef]

65. Rigueiro-Rodríguez, A.; Mosquera-Losada, M.R.; Fernández-Núñez, E. Afforestation of agricultural land with Pinus radiata D. Don and Betula alba L. in NW Spain: Effects on soil pH, understorey production and floristic diversity eleven years after establishment. Land Degrad. Dev. 2012, 23, 227-241. [CrossRef]

66. Łętowska, A.; Strączyńska, S. Wybrane właściwości fizykochemiczne i chemiczne gleb odłogowanych i użytkowanych rolniczo. Zesz. Probl. Postępów Nauk. Rol. 2001, 478, 241-248. (In Polish)

67. Strączyńska, S.; Zawieja, J. Zmiana fitocenozy i niektórych właściwości gleby pod wpływem jej wieloletniego odłogowania. Zesz. Probl. Postęów Nauk. Rol. 2001, 478, 327-333. (In Polish)

68. Smal, H.; Ligęza, S.; Olszewska, M. Zmiany właściwości gleb lekkich porolnych pod wpływem zalesienia sosną (wstępne wyniki badań). Zesz. Probl. Postępów Nauk. Rol. 2003, 493, 491-498. (In Polish)

69. Smal, H.; Ligęza, S.; Olszewska, M. Wpływ zalesienia piaszczystych gleb porolnych na jakość materii organicznej i skład chemiczny roztworu glebowego. Rocz. Glebozn. 2004, 55, 139-148. (In Polish)

70. Brożek, S.; Zwydak, M. Atlas Gleb Leśnych Polski; CILP: Warszawa, Poland, 2010. (In Polish)

71. Podrázský, V.V.; Ulbrichová, I. Restoration of forest soils on reforested abandoned agricultural lands. J. For. Sci. 2004, 50, 249-255. [CrossRef]

72. Uri, V.; Kukumägi, M.; Aosaar, J.; Varik, M.; Becker, H.; Morozov, G.; Karoles, K. Ecosystems carbon budgets of differently aged downy birch stands growing on well-drained peatlands. For. Ecol. Manag. 2017, 399, 82-93. [CrossRef]

73. Varik, M.; Aosaar, J.; Ostonen, I.; Lõhmus, K.; Uri, V. Carbon and nitrogen accumulation in belowground tree biomass in a chronosequence of silver birch stands. For. Ecol. Manag. 2013, 302, 62-70. [CrossRef] 